\title{
SOME URBAN POLICY CONSIDERATIONS OF RURAL JOURNEY-TO-WORK COMMUTING
}

\author{
Charles F. Floyd and Terry D. Robertson
}

The University of Georgia

A primary cause of many of the current inner-city urban problems has been the large number of unskilled and untrained rural-to-urban migrants who moved to the cities because of a lack of job opportunity in their home communities. ${ }^{1}$ Many of these migrants were almost completely unprepared for either the social or economic demands of urban life. As a result, a large portion of the group failed to be absorbed into the mainstream of economic activity, thereby leading to increased expenditures of public funds and intensifying urban social problems. Therefore, although this flow of rural-to-urban migrants has moderated in recent years, it still appears that if the cities are to solve many of their present problems, the tide of rural-to-urban migrants must be reduced substantially.

Since migration has been away from areas of high underemployment or unemployment toward areas of actual or supposed economic opportunity, it seems that the most effective means of stemming this rural-to-urban shift is to create more opportunity for rural residents. Development policy attempted to do this by creating jobs in depressed rural areas. It was dis covered, however, that this type policy was not effective since the underdeveloped areas generally lack locational advantages, other than a low-cost labor force, and therefore, direct public investment had little economic impact or effect.

Modification of previous policies resulted in the concept of direct investment in regional "growth centers." This policy attempts to invest funds in a growing locality and to affect notonly the immediate community but also a surrounding "labor-shed" which is economically depressed. Therefore, for the program to succeed, individuals in outlying depressed areas must have the ability and willingness to commute.

Since the ability and willingness of rural area workers to commute are so critical to the success of the growth center strategy, this paper will examine the experience of several Georgia employers. The firms are two electrical equipment manufacturers in Athens, a designated Economic Development Administration "growth center," Lockheed Georgia Corporation in Marietta, and Warner Robins Air Force Base in Warner Robins.

\section{TABLE I. EMPLOYEES BY COUNTY}

\begin{tabular}{|c|c|c|c|c|}
\hline County & $\begin{array}{l}\text { Reliance } \\
\text { Elec. Co. }\end{array}$ & $\begin{array}{l}\text { Percent of } \\
\text { Total }\end{array}$ & $\begin{array}{l}\text { Other } \\
\text { Elec. Co. }\end{array}$ & $\begin{array}{l}\text { Percent of } \\
\text { Total }\end{array}$ \\
\hline$\overline{\text { Clarke }}$ & 71 & 47.0 & 331 & 37.4 \\
\hline Madison & 27 & 17.9 & 193 & 21.8 \\
\hline Jackson & 21 & 13.9 & 161 & 18.2 \\
\hline Oconee & 14 & 9.3 & 82 & 9.2 \\
\hline Franklin & 9 & 6.0 & 24 & 2.7 \\
\hline Oglethorpe & 5 & 3.3 & - & - \\
\hline Barrow & - & - & 21 & 2.4 \\
\hline Other & 4 & 2.6 & 72 & 8. 1 \\
\hline TOTAL & $\overline{151}$ & $\overline{100.0}$ & $\overline{884}$ & $\overline{100.0}$ \\
\hline
\end{tabular}

Source: Personnel Departments of Subject Companies 
FIGURE I

\section{ELECTRICAL COMPANIES LABOR SHED}

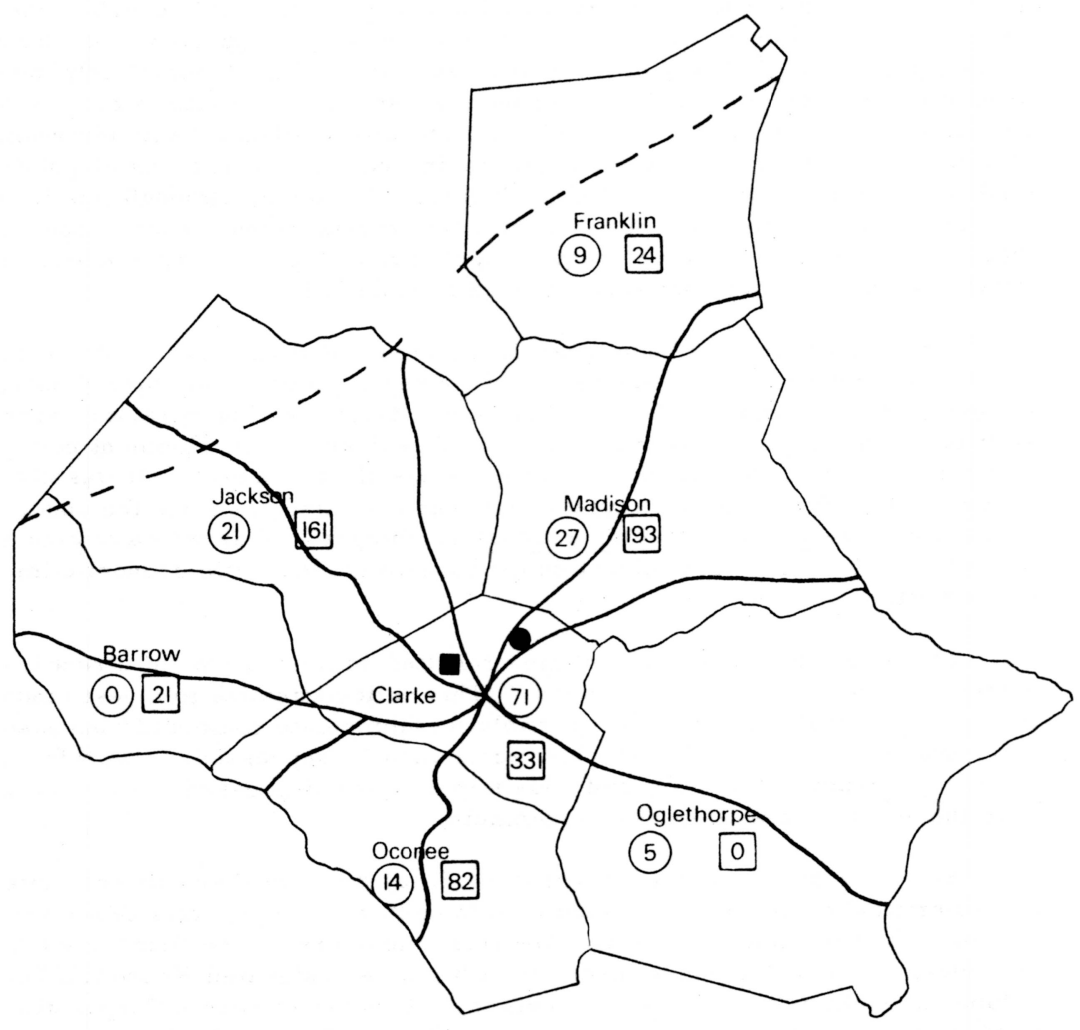

\section{LEGEND}

reliance

$\square$ OTHER ELECTRICAL COMPANY

- - INTERSTATE

OTHER ROADS

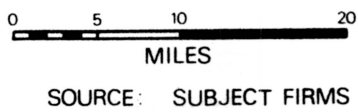


The two electrical equipment manufacturing firms have very similar labor-sheds. One, Reliance Electric Company, having begun operation only recently, has extended the spatial extent of commuting slightly further than the other firm which was already established. Table I and Table II, indicating the resident counties of employees of both firms and their commuting distances, suggest that these firms draw upon a rural labor force which resides from ten to forty miles away. Figure graphically illustrates both the labor-shed and main commuting routes used in the journey to work.

TABLE II. EMPLOYEES BY DISTANCE TO RESIDENCE

\begin{tabular}{|c|c|c|c|c|}
\hline Miles & $\begin{array}{l}\text { Reliance } \\
\text { Elec. Co. }\end{array}$ & $\begin{array}{l}\text { Percent of } \\
\text { Total }\end{array}$ & $\begin{array}{l}\text { Other } \\
\text { Elec. Co. }\end{array}$ & $\begin{array}{l}\text { Percent of } \\
\text { Total }\end{array}$ \\
\hline $0-9$ & 69 & 49.3 & 424 & 52.1 \\
\hline $10-14$ & 20 & 14.3 & 66 & 8.1 \\
\hline $15-19$ & 18 & 12.8 & 240 & 29.6 \\
\hline $20-24$ & 18 & 12.8 & 58 & 7. 1 \\
\hline $25-29$ & 6 & 4. 3 & - & - \\
\hline $30+$ & 9 & 6.5 & 24 & 3.0 \\
\hline TOTAL & $\overline{140}$ & $\overline{100.0}$ & $\overline{812}$ & $\overline{100.0}$ \\
\hline
\end{tabular}

Source: Personnel Departments of Subject Firms

The Reliance Electric Company, which benefited from an Economic Development Administration grant to the City of Athens, can also be utilized as a measure of the impact of a new firm in a growth center. The data in Table III give an indication of the firm's economic impact on and relative importance to surrounding low income counties. The wages paid by both electrical manufacturing firms accounted for large portions of manufacturing incomes in Madison, Oconee, and Oglethorpe counties, equal to 54.4 percent of manufacturing wages and salaries earned in Madison County to 3.1 percent of manufacturing wages and salaries earned in Oglethorpe County. Reliance, a new firm not yet developed to planned capacity, still accounted for significant porportions of the incomes in the three counties, 7.0 percent in Madison County to 3.1 percent in Oglethorpe County.

\section{TABLE III. EARNINGS BY RESIDENTS IN SUBJECT COMPANIES COMPARED TO MANUFACTURING EARNINGS OF COUNTIES}

\begin{tabular}{|c|c|c|c|c|c|}
\hline County & $\begin{array}{l}1967 \\
\text { Manufacturing } \\
\text { Income }\left(000^{\prime} \mathrm{s}\right)\end{array}$ & $\begin{array}{l}\text { Reliance } \\
\text { Elec. Wages } \\
\text { and Salaries } \\
\end{array}$ & $\begin{array}{l}\text { Percent } \\
\text { of County } \\
\text { Total }\end{array}$ & $\begin{array}{l}\text { Other } \\
\text { Firm Wages } \\
\text { and Salaries }\end{array}$ & $\begin{array}{l}\text { Percent } \\
\text { of County } \\
\text { Total } \\
\end{array}$ \\
\hline $\overrightarrow{\text { Barrow }}$ & 12,622 & - & $\overline{-}$ & 97,440 & .7 \\
\hline Clarke & 36,476 & 329,440 & .9 & $1,535,840$ & 4.2 \\
\hline Franklin & 5,723 & 41,760 & .7 & 111,360 & 1.9 \\
\hline Jackson & 14,444 & 97,440 & .7 & 747,040 & 5.2 \\
\hline Madison & 1,792 & 125,280 & 7.0 & 849,120 & 47.4 \\
\hline Oconee & 1,868 & 64,960 & 3.5 & 380,480 & 20.4 \\
\hline Oglethorpe & 749 & 23,230 & 3.1 & - & - \\
\hline TOTAL & $\overline{73,674}$ & 755,784 & $\overline{1.0}$ & $\overline{3,721,280}$ & 5.1 \\
\hline
\end{tabular}

Source: Estimated from data received from subject companies and Regional Economic Division, Office of Business Economics

Lockheed-Georgia Company, a large aircraft manufacturer, employed 22,597 Georgia residents in 1968. The indication of the data in Table IV is that workers will commute quite long distances to relatively high wage jobs, 20.3 percent of the Lockheed-Georgia workers commuting over 20 miles. These figures do not include persons commuting from out of state, mainly from Tennessee and Alabama. The labor area and main commuting routes are shown in Figure II. 
FIGURE 2

LOCKHEED - GEORGIA COMMUTING AREA

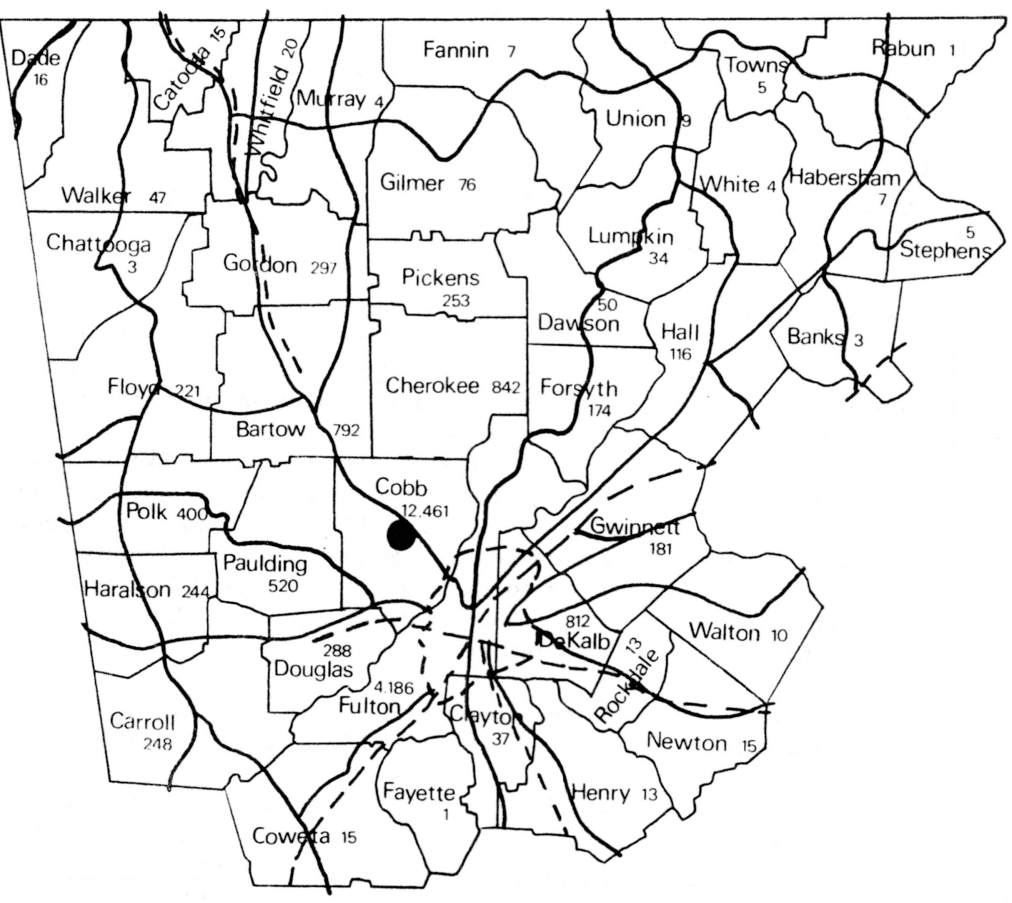

\section{LEGEND}

LOCKHEED 
TABLEIV. LOCKHEED-GEORGIA EMPLOYEES - DISTANCE TO RESIDENCE

\begin{tabular}{lrr} 
Miles & $\begin{array}{c}\text { Number of } \\
\text { Employees }\end{array}$ & $\begin{array}{r}\text { Percent of } \\
\text { Total }\end{array}$ \\
\cline { 3 - 3 } $10-19$ & $\begin{aligned} 12,461 \\
5,559\end{aligned}$ & 24.6 \\
$20-29$ & 2,305 & 10.2 \\
$30-39$ & 536 & 2.4 \\
$40-49$ & 1,386 & 6.1 \\
$50-59$ & 120 & .5 \\
$60-69$ & 40 & .2 \\
$70-79$ & 70 & .3 \\
$80-89$ & 91 & .4 \\
$90-99$ & 10 & .1 \\
$100+$ & 19 & 100.0 \\
TOTAL & 22,597 &
\end{tabular}

Source: Lockheed-Georgia Co.

Another large employer, Warner Robins Air Force Base, has a laborshed around the Macon SMSA in central Georgia. Table V and FigureIIIindicate widespread residence of employees with 19 percent of the work force of 18,541 traveling farther than 20 miles and 11.4 percent from farther than 30 miles.

\section{TABLEV. WARNER ROBINS AIR FORCE BASE EMPLOYEES BY DISTANCE TC RESIDENCE}

\begin{tabular}{|c|c|c|}
\hline Miles & $\begin{array}{l}\text { Number of } \\
\text { Employees }\end{array}$ & $\begin{array}{l}\text { Percent of } \\
\text { Total }\end{array}$ \\
\hline$\overline{0-9}$ & 7,606 & 41.2 \\
\hline $10-19$ & 7,287 & 39.5 \\
\hline $20-29$ & 1,401 & 7.6 \\
\hline $30-39$ & 1,356 & 7.3 \\
\hline $40+$ & 801 & 4. 1 \\
\hline TOTAL & $\overline{18,451}$ & $\overline{100.0}$ \\
\hline
\end{tabular}

Source: Public Information Office, Warner Robins Air Force Base

The evidence presented by this study and a study of two North Carolina firms by Lonsdale seems to verify the contention that workers will commute relatively long distances to work, but that the size of the labor-shed is limited by the wage levels offered by the employing firm and also by the presence or absence of adequate transportation routes. ${ }^{2}$ Both relatively high wages and good transportation are present in the Lockheed-Georgia case and offer an explanation as to why that labor-shed extends over so wide an area. On the other hand, the residences of the apparel workers studied by Lonsdale, who received very low wages in comparison with most manufacturing employees, were concentrated within fifteen miles of the employer. ${ }^{3}$ The commuting field for the lower wage Warner Robins workers was also considerably smaller than for the higher wage personnel. The implication is that if additional employment in the growth centers is to be of significant benefit to the surrounding rural areas, the wage levels offered by new employers must be relatively higher than existing wage levels in outlying a reas to make commuting feasible. Also, an adequate system of transportation is essential. 
FIGURE 3

WARNER ROBINS LABOR SHED

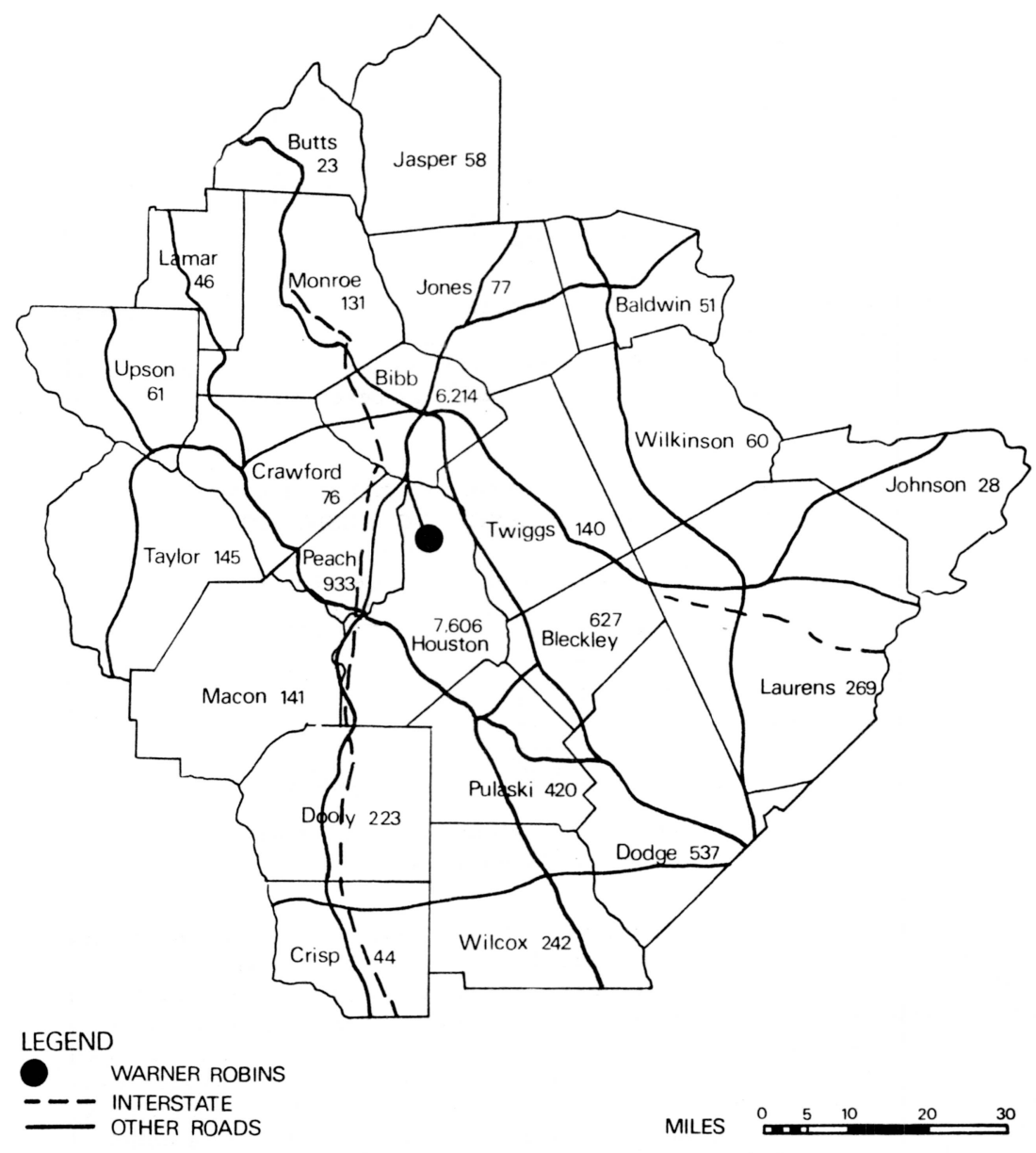

SOURCE: OFFICE OF INFORMATION. WRAMA, WARNER ROBINS AIR FORCE BASE 


\section{Policy Conclusions}

It appears that rural residents will commute relatively long distances to work over extended periods if job opportunity and wage levels a re considerably higher in the employment center than in their home communities. An important policy consideration is, therefore, whether it might be less expensive and more feasible to create rural jobs by subsidizing journey-to-work commuting for certain workers than to subsidize industrial location in rural areas or rural-to-urban migration.

Over the past few years, several programs have subsidized relocation of unemployed and underemployed ru ral workers in urban centers. Generally, the programs have been only moderately successful. First, the return rate is very high. For example, in one North Carolina project, only one-third of those relocated remained in the relocation area for as long as one year. 4 Even for the successful migrants, the public costs were quite large. ${ }^{5}$ In addition, even when the relocated workers can gain employment, they often are still not prepared for urban life and the reby intensify urban social problems. Subsidized commuting, on the other hand, requires only an adjustment to different employment habits, not the complete adjustment to an urban way of life.

Some of the rural poor lack not only the skills necessary to qualify them for employment in growth centers but also lack the ability to commute to available jobs or to job training. For the workers, free or heavily subsidized transportation to training or employment may be necessary in order for them to enter the non-agricultural labor force. These subsidies would not have to be of a permanent nature, since once employed, the rural residents could accumulate the means necessary to purchasetransportation services.

Other workers could be encouraged to remain in rural areas by providing a tax incentive for journey-to-work commuting. If commuting expenses for rural workers were made income tax deductible, this would make commuting relatively more desirable compared to migration, and would reduce the incentive to leave the rural area. 


\section{FOOTNOTES}

${ }^{1}$ The authors wish to thank Howard B. Montgomery and James N. Adams for their help in gathering the commuting data.

${ }^{2}$ Richard E. Lonsdale, "Two North Carolina Commuting Patterns," Economic Geography, XLII, April, 1966, pp. 114-148.

${ }^{3}$ Ibid. , p. 128.

${ }^{4}$ Charles K. Fairchild, "Subsidized Relocation of the Rural Unemployed: Benefits and Costs, "Paper delivered at the meeting of the Southern Economic Association, St. Louis, Mo., November, 1969, p. 7.

${ }^{5}$ Ibid. 